\title{
EKSEKUTORIAL PUTUSAN PTUN SEBAGAI LEMBAGA YUDIKATIF
}

\author{
ARY WAHYUDI \\ UNIVERSITAS ISLAM AL - AZHAR \\ Aryw3274@gmail.com
}

\begin{abstract}
Abstrak
Lahirnya Peradilan Tata Usaha Negara dapat disimpulkan merupakan tuntutan masyarakat Indonesia yang merasa haknya sebagai warga negara dilanggar oleh pemerintah, selain itu untuk mencegah terjadinya maladministrasi, serta segala bentuk penyalahgunaan wewenang oleh pemerintah. Namun dalam perkembangan dibentuknya Peradilan Tata Usaha Negara di Indonesia, lemahnya kekuatan hukum Putusan PTUN membuat masyarakat cemas akan kekuatan hukum dari putusan PTUN yang membawa angin kedamaian bagi masyarakat yang dilanggar haknya oleh pemerintah. Masyarakat menjadi ragu akan kekuatan hukum yang dimiliki oleh lembaga peradilan ini dalam menegakkan keadilan manakala terjadi penyalahgunaan wewenang oleh pemerintah. Lemahnya kekuatan hukum putusan PTUN ini disebabkan beberapa kendala yaitu: Tidak adanya lembaga eksekutorial khusus atau lembaga sanksi yang berfungsi untuk melaksanakan putusan, rendahnya tingkat kesadaran pejabat Tata Usaha Negara dalam menaati putusan Pengadilan Tata Usaha Negara, serta tidak adanya pengaturan yang lebih tegas mengenai pelaksanaan putusan Pengadilan Tata Usaha Negara. Untuk memperjelas hal ditas maka dalam tulisan ini diajukan tiga rumusan masalah utama yakni Bagiamanakah bentuk putusan sela dalam dalam peradilan, bagaimanakah mekanisme pelaksanaan putusan (eksekutorial) PTUN, dan bagaimana kekuatan eksekutorial putusan PTUN. Yang dianalisis dengan metode Yuridis Normatif.
\end{abstract}

Kata Kunci : Putusan Sela, Kekuatan Eksekutorial, Mekanisme PTUN, Hambatan dan Upaya. 


\section{A. PENDAHULUAN}

Problema eksekusi putusan lembaga Peradilan Tata Usaha Negara (PTUN) merupakan suatu fenomena hukum yang bersifat umum yang selama ini sering terjadi, dan salah satu yang terus mengemuka dan problematik, adalah terkait lembaga eksekutorial yang berfungsi sebagai tindak lanjut atas putusan pengadilan (gerechtelijke tenuitvoerlegging atau execution force) serta bertujuan untuk mengefektifkan pelaksanaan suatu putusan yang isinya membebankan kewajiban (prestasi) bagi pihak yang dikalahkan di pengadilan. ${ }^{1}$ Dari norma hukum positif dan praktek yang berlangsung hingga saat ini, permasalahan eksekusi terus mengemuka, bahkan menjadi perdebatan antara para pihak yang berperkara dan diskusi yang tiada henti di kalangan akademisi maupun praktisi hukum. Terutama apabila yang dimohonkan untuk patuh terhadap isi putusan pengadilan itu adalah Pemerintah yang kalah dalam proses persidangan.

Padahal jika ditelisik lebih jauh, prinsip adanya PTUN, adalah untuk menempatkan kontrol yudisial dalam penyelenggaraan pemerintahan yang baik supaya tidak menjadi bias dalam sistem ketatanegaraan Indonesia. Bila suatu putusan PTUN tidak memiliki kekuatan eksekutorial, bagaimana mungkin hukum dan masyarakat dapat mengawasi jalannya pemerintah yang dilaksanakan oleh pejabat-pejabat PTUN. Imbasnya masalah ketidakpatuhan Badan atau Pejabat Tata Usaha Negara dalam melaksanakan putusan Pengadilan Tata Usaha Negara sering kita lihat terjadi akhir-akhir ini. Sebagaimana hal ini dikemukakan oleh Supandi dalam penelitian disertasinya yang menyebutkan masih sering terjadi putusan Pengadilan Tata Usaha Negara yang tidak dilaksanakan/dipatuhi oleh Pejabat Tata Usaha Negara yang bersangkutan, sehingga dapat menimbulkan ketidakpastian hukum dalam pelaksanaan pemerintahan dan pembangunan Disamping ketidakpatuhan Pejabat, Supandi juga melihat dari sisi lemahnya sistem eksekusi yang diatur di dalam Undang-Undang Nomor 5 Tahun 1986 tentang Peradilan TUN menyebabkan masyarakat

1 Simon Butt, The Eksekusi of the Negara Hukum : Implementing Judicial Decision in Indonesia, dalam Timothy Lindsey (Editor), Indoneisa : Law and Society, (The Federation Press, Melbourne, 1999), hlm. 250. 
masih pesimistis terhadap eksistensi lembaga Peradilan Tata Usaha Negara. ${ }^{2}$

Jika ditelisik lebih jauh dengan berbagai penyebab diatas, secara general kita akan menemukan beberapa faktor yang menyebabkan lemahnya eksekusi putusan PTUN yang telah berkekuatan hukum tetap, yaitu: Pertama, ketiadaan aturan hukum yang memaksa bagi Pejabat TUN untuk melaksanakan putusan Pengadilan yang telah berekuatan hukum tetap. Kedua, faktor amar putusan hakim yang tidak berani mencantumkan pembayaran uang paksa apabila pejabat TUN yang bersangkutan tidak melaksanakan putusan Pengadilan, dan Ketiga, adalah faktor kepatuhan Pejabat TUN dalam menjalankan putusan Pengadilan yang telah berkekuatan hukum tetap. Permasalahan eksekusi putusan PTUN ini juga dapat timbul terkait dengan diberlakukannya otonomi daerah, karena dengan adanya otonomi daerah seluruh pejabat kepala daerah di kabupaten/kota memiliki kewenangan yang luas dalam mengelola daerahnya dan hal tersebut pasti menggunakan metode keputusan-keputusan administrative. ${ }^{3}$

Kondisi diatas seolah mengkonfirmasi masih jauhnya penerapan dari Fungsi dibentuknya PTUN itu sendiri yang seharusnya dapat mendorong terwujudnya pemerintah yang bersih dan berwibawa yaitu terciptanya suasana sikap tidak dari unsur Negara yang bersifat penegakan dari persoalan yang cacat hukum. Hal itu disebabkan sekali lagi oleh putusan PTUN yang pertimbangan hukum beserta diktumnya berisi pernyataan tidak sahnya suatu KTUN yang dinilai melanggar peraturan perundang-undangan yang berlaku dan / atau asas-asas umum pemerintahan yang baik (AAUPB), seharusnya dapat memberikan dorongan bagi pemerintah yaitu badan atau pejabat tata usaha Negara untuk memperbaiki sistem dan kinerjanya dalam menyelenggarakan fungsi

${ }^{2}$ Supandi, "Kepatuhan Pejabat Dalam Menaati Putusan Pengadilan Tata Usaha Negara”, (Disertasi Program Pascasarjana Universitas Sumatera Utara; Medan), 2005, hlm. 266.

3 Jimly Assiddiqie, Sengketa Kewenangan Antar Lembaga Negara, (Konstitusi Press, Jakarta), 2006, 45. 
pemerintah guna mewujudkan pemerintah yang bersih dan berwibawa (clean and strong government). ${ }^{4}$

Bahkan lebih jauh, dalam penelitian Adriaan Bedner mengenai PTUN di Indonesia, ditemukan permasalahan mengenai eksekusi. Menurutnya, pengaturan eksekusi dalam Undang-Undang PTUN menimbulkan kesalahpahaman mengenai kemandirian lembaga peradilan, yaitu agar dilaksanakan isi putusan PTUN harus meminta kepada atasan pejabat eksekutif yang dijadikan tergugat agar dipatuhi isi putusannya tersebut, karena atasan pejabat eksekutiflah yang dianggap memiliki hak veto. Pengaturan prosedur ini karena penyusun undang-undang sadar bahwa pejabat-pejabat di Indonesia enggan mematuhi perintah pengadilan. $^{5}$

Selain itu, ada beberapa kasus yang menurut atasan pejabat yang dijadikan tergugat tidak berkenan melaksanakan isi putusan karena bersifat sensitif yang diasumsikan dapat membahayakan stabilitas masyarakat dan politik. Dalam banyak kasus akan tetapi sulit pembuktiannya, bahwa pejabat mencoba menekan hakim, namun tidak diragukan lagi bahwa pertimbangan politik telah mempengaruhi sejumlah putusan. ${ }^{6}$ Atas dasar itu tampaknya permasalahan utama dalam penegakan hukum administrasi oleh PTUN adalah terkait pelaksanaan isi putusan PTUN (eksekutorial). Banyak putusan PTUN tidak dilaksanakan oleh badan dan/atau pejabat pemerintahan (baik yang duduk sebagai tergugat maupun atasan pihak tergugat itu sendiri), tanpa ada alasan hukum yang jelas. Keadaan yang demikian tentunya selain merugikan para pencari keadilan, juga menghambat tegaknya negara hukum di Indonesia.

Sehingga Dalam tulisan ini, akan diuraikan secara general terkait PTUN dan langkah eksekusi di lembaga Peradilan Tata Usaha Negara

${ }^{4}$ Arifin Marpaung, "Pelaksanaan Putusan Pengadilan Tata Usaha Negara Melalui Upaya Paksa”, (Disertasi Program Pascasarjana Universitas Airlangga Surabaya, 2010), hlm. 7.

5 Adrian Bedner, Administrative Courts in Indonesia : A Socio-Legal Study (Terjemahan), (London, The Hague: Kluwer International, 2003), hlm. 151 dan 252.

6 Adrian Bedner, Administrative Courts in Indonesia : A Socio-Legal Study (Terjemahan), (London, The Hague: Kluwer International, 2003), hlm. 151 dan 252. 
(PTUN). Sebagai imbas daru Undang-undang yang mengatur hukum formil PTUN, belum secara tegas dan rinci mengatur pelaksanaan eksekusi di Pengadilan Tata Usaha Negara (PTUN).

\section{B. Rumusan penelitian}

Mengacu pada pembahasan pendahuluan diatas serta untuk mempertegas beberapa aspek yang dibahas dalam tulisan ini, dirumuskan tiga pertanyaan seperti dibawah ini:

1. Bagaimana Bentuk putusan sela dalam dalam peradilan?

2. Seperti apa mekanisme pelaksanaan putusan (eksekutorial) PTUN?

3. Bagaimana Kekuatan eksekutorial putusan PTUN?

\section{METODE PENELITIAN}

Dalam Penelitian ini menggunakan jenis penelitian Yuridis Normatif, yaitu penelitian yang fokus terhadap kajian penerapan kaidah-kaidah atau norma-norma hukum positif yang berlaku. ${ }^{7}$ Penelitian yuridis normatif dilakukan dengan cara mengkaji bermacam macam aturan hukum yang bersifat formal seperti peraturan perundang-undangan, referensi konsep teoritis yang dihubungkan dangan permasalahan yang menjadi topik pembahasan. ${ }^{8}$

Pendekatan yang digunakan adalah pendekatan undang-undang (statute approach) dan pendekatan konseptual (conceptual approach). Pendekatan perundang-undangan (statute approach) dilaksanakan dengan menggunakan telaahan terhadap seluruh undang-undang dan regulasi yang terkait dengan isu hukum yang sedang dibahas. Pendekatan konseptual (conceptual approach) adalah pendekatan yang dilakukan dengan cara mempelajari pandangan-pandangan dan doktrin-doktrin ilmu hukum, konsep-konsep hukum dan asas-asas hukum yang relevan dengan isu yang menjadi topik permasalahan. ${ }^{9}$

Metode yang digunakan adalah Metode pengumpulan data yang diperoleh melalui penelitian kepustakan (library research) terhadap bahan

7 Johny Ibrahim, Teori Metodologi Penelitian Hukum Normatif (Malang: Banyu Media, 2008) hlm. 295

8 Peter Mahmud Marzuki, Penelitian Hukum (Jakarta: Kencana Prenada Media Group, 2010). hlm. 29

9 Peter Mahmud Marzuki, Penelitian Hukum (Jakarta: Kencana Prenada Media Group, 2010). hlm. 136. 
hukum primer seperti Undang-Undang Dasar Negara Republik Indonesia Tahun 1945, Undang-undang Nomor 51 Tahun 2009 tentang Perubahan Kedua Atas Undang-undang Nomor 5 Tahun 1986 tentang Peradilan Tata Usaha Negara, Indonesia, Undang-undang Nomor 51 Tahun 2009 tentang Perubahan Kedua Atas Undang-undang Nomor 5 Tahun 1986 tentang Peradilan Tata Usaha Negara Indonesia, Undang-undang Nomor 30 Tahun 2014 tentang Administrasi Pemerintahan, bahan hukum sekunder bersumber.

\section{PEMBAHASAN}

\section{A. Macam-Macam Putusan PTUN}

Putusan Hakim atau biasa disebut dengan Putusan Pengadilan merupakan sesuatu yang sangat diinginkan atau dinantikan oleh pihakpihak yang berperkara guna menyelesaikan sengketa mereka dengan sebaik-baiknya. Sebab dengan putusan hakim tersebut pihakpihak yang besengketa mengharapkan adanya kepastian hukum dan keadilan dalam perkara yang mereka hadapi. Putusan Hakim merupakan suatu pernyataan oleh hakim sebagai pejabat yang diberi wewenang untuk itu, diucapkan dipersidangan dan bertujuan untuk mengakhiri atau menyelesaikan suatu perkara atau sengketa antara para pihak. Adapun macam-macam putusan hakim atau putusan pengadilan terdiri dari Putusan yang belum mengakhiri sengketa yang dinamakan putusan sela dan Putusan akhir. Selain itu dalam Hukum acara PTUN ada juga yang dikenal dengan Putusan Dismissal. ${ }^{10}$

Adapun macam-macam putusan PTUN itu adalah sebagai berikut : 1 . Putusan Dismissal; 2. Putusan Sela; dan 3. Putusan Akhir. ${ }^{11}$

\section{Putusan Dismissal}

Putusan Dismissal merupakan putusan yang dikeluarkan oleh PTUN dalam proses dismissal, Proses dismissal merupakan proses penyaringan

10 Jimly Asshiddiqie, Negara Hukum Indonesia, Ceramah Umum dalam rangka Pelantikan Dewan Pimpinan Pusat Ikatan Alumni Universitas Jayabaya, di Jakarta, Sabtu, 23 Januari 2010.

${ }^{11}$ Jimly Asshiddiqie, Konstitusi dan Kostitusionalisme Indonesia, (Jakarata : Sinar Grafika, 2010), 76. 
untuk menghindari asal gugat karena pemerintahan yang baik memerlukan kepastian hukum. Proses ini yang membedakan dengan beracara di lingkungan peradilan lainnya, sehingga perkaraperkara yang lolos proses dismissal diharapkan betul-betul perkara yang menjadi wewenang PTUN untuk memeriksa, memutus dan menyelesaikannya. ${ }^{12}$

Ketua PTUN memutuskan dengan suatu Penetapan yang dilengkapi Dengan pertimbangan-pertimbangan bahwa gugatan yang di Diajukan dinyatakan tidak diterima atau tidak berdasar sesuai yang ditentukan dalam Pasal 62 Undang- Undang tentang PTUN dalam hal ini :

a. Pokok gugatan nyata-nyata tidak termasuk dalam wewenang pengadilan;

b. Syarat-syarat sebagaimana dimaksud dalam Pasal 56 UU Peraturan tidak terpenuhi oleh Penggugat meskipun ia telah diberitahu dan diperingatkan,

c. Gugatan tersebut tidak didasarkan pada alasan yang layak.

d. Apa yang dituntut dalam gugatan sebenarnya sudah terpenuhi oleh keputusan TUN yang digugat.

e. Gugatan diajukan sebelum waktunya atau telah lewat waktunya.

Terhadap penetapan Ketua PTUN tersebut dapat diajukan gugatan perlawanan dalam tenggang waktu 14 hari setelah diucapkan. Perkara perlawanan diperiksa oleh Majelis Hakim dengan acara singkat pemeriksaan dalam acara singkat memang tidak diatur didalam UndangUndang Peraturan, akan tetapi didalam praktek pemeriksaan dilakukan tidak dengan persidangan karena tidak sampai kepada materi gugatannya, akan tetapi hanya memeriksa apakah pertimbangan di dalam penetapan Ketua PTUN yang pada pokoknya menyatakan gugatan tidak lolos dismissal apakah sudah sesuai dengan Pasal 62 Undang-Undang

${ }^{12}$ Jimly Asshiddiqie, Konstitusi dan Kostitusionalisme Indonesia, (Jakarata : Sinar Grafika, 2010), 77. 
Peraturan ataukah tidak. ${ }^{13}$ Meskipun perkara perlawanan diperiksa dengan cara singkat, akan tetapi Putusan diucapkan dalam sidang yang terbuka untuk umum. Dalam hal perlawanan tersebut dibenarkan oleh Pengadilan, maka penetapan Ketua PTUN gugur demi hukum dan pokok gugatan akan diperiksa dengan acara biasa. Terhadap Putusan mengenai gugatan perlawanan, tidak dapat digunakan upaya hukum, yang artinya sudah berkekuatan hukum tetap.

\section{Putusan Sela}

Putusan sela adalah putusan yang dijatuhkan sebelum putusan akhir yang diadakan dengan tujuan untuk memungkinkan atau mempermudah kelanjutan pemeriksaan perkara. Dalam Konteks hukum acara Peradilan Tata Usaha Negara, putusan sela adalah putusan yang dijatuhkan oleh hakim sebelum pemeriksaan sengketa Tata Usaha Negara dinyatakan selesai. ${ }^{14}$

Dalam Hukum Acara Tata Usaha Negara, yang termasuk putusan yang bukan putusan akhir contohnya adalah :

a. putusan hakim yang memerintahkan kepada penggugat atau tergugat untuk datang menghadap sendiri kepemeriksaan siding pengadilan meskipun sudah diwakili oleh seorang kuasa.

b. putusan Hakim Ketua sidang yang mengangkat seseorang ahli alih bahasa atau seorang yang pandai bergaul dengan penggugat atau saksi sebagai juru bahasa.

c. Putusan hakim ketua sidang yang menunjuk seseorang atau beberapa ahli atas permintaan penguggat dan tergugat atau penggugat atau tergugat karena jabatannya.

d. Putusan hakim mengenai beban pembuktian.

${ }^{13}$ Jimly Asshiddiqie, Konstitusi dan Kostitusionalisme Indonesia, (Jakarata : Sinar Grafika, 2010), 77.

14 Jimly Assiddiqie, Sengketa Kewenangan Antar Lembaga Negara, Konstitusi Press. Jakarta, 2006), 53. 


\section{Putusan Akhir}

Putusan Akhir adalah putusan yang dijatuhkan oleh hakim setelah pemeriksaan sengketa Tata Usaha Negara selesai yang mengakhiri sengketa tersebut pada tingkat pengadilan tertentu. Putusan akhir menurut sifat amarnya dapat dibedakan atas tiga macam yaitu: ${ }^{15}$

1. Putusan Condemnatoir yaitu putusan yang bersifat menghukum pihak yang dikalahkan untuk memenuhi prestasi (to het verrichten van een pretatie)

2. Putusan Declaratoir yaitu putusan hakim yang menyatakan apa yang menjadi hukum. putusan hakim yang menyatakan permohonan atau gugatan ditolak merupakan suatu putusan yang bersifat declaratoir.

3. putusan constitutief adalah putusan yang meniadakan suatu keadaan hukum atau menciptakan suatu keadaan hukum yang baru.

4. Putusan Pengadilan tata Usaha Negara menurut Pasal 97 ayat (7) Undang-Undang No.5 Tahun 1986 Tentang Pengadilan tata Usaha Negara terdiri dari :

\section{Gugatan ditolak}

Putusan yang berupa gugatan ditolak adalah putusan yang menyatakan bahwa keputusan Tata Usaha Negara yang menimbulkan sengketa Tata Usaha Negara adalah Keputusan Tata Usaha Negara yang tidak dinyatakan batal atau sah.

2. Gugatan dikabulkan

Putusan yang berupa gugatan dikabulkan adalah putusan yang menyatakan bahwa keputusan Tata Usaha Negara yang

15 Jimly Assiddiqie, Sengketa Kewenangan Antar Lembaga Negara, Konstitusi Press. Jakarta, 2006), 54. 
menimbulkan sengketa Tata Usaha Negara adalah Keputusan Tata Usaha Negara yang dinyatakan batal atau tidak sah.

Oleh karena gugatan Pasal 97 ayat (8) Undang-undang No.5 Tahun 1986 Tentang Pengadilan tata usaha negara ditentukan bahwa dalam hal gugatan dikabulkan maka dalam putusan tersebut dapat ditetapkan kewajiban yang harus ditentukan dalam pasai 97 ayat (9) Undang-Undang No.5 Tahun 1986 Tentang Pengadilan tata Usaha Negara yang berupa: ${ }^{16}$

a. pencabutan Keputusan Tata Usaha Negara yang bersangkutan; atau

b. pencabutan Keputusan Tata Usaha Negara yang bersangkutan dan menerbitkan Keputusan Tata Usaha Negara yang baru; atau

c. penerbitan Keputusan Tata Usaha Negara dalam hal gugatan didasarkan pada Pasal 3.

3. Gugatan tidak diterima

Putusan yang berupa gugatan tidak diterima adalah putusan yang menyatakan bahwa syarat-syarat yang telah ditentukan tidak dipenuhi oleh gugatan yang diajukan oleh penggugat.

4. Gugatan Gugur

Putusan yang berupa gugatan gugur adaiah putusan yang dijatuhkan hakim karena penggugat tidak hadir dalambeberapa kali sidang meskipun telah dipanggil dengan patut atau penggugat meninggal dunia.

Dengan melihat amar Putusan Pengadilan Tata Usaha Negara Mataram dengan nomor 31/G/2010/PTUN-MTR telah memiliki kekuatan hukum tetap(in kracht van gewijsde), yang menyatakan: a. Mengabulkan gugatan Pengugat sebagian, b. Menyatakan

16 Jimly Assiddiqie, Sengketa Kewenangan Antar Lembaga Negara, (Konstitusi Press. Jakarta, 2006), 64 
Keputusan KPUD Lombok Tengah No.27 Tahun 2010. c. entang Penetapan Pasangan Calon Kepala Daerah Dan Wakil Kepala Daerah menjadi peserta pemilihan umum kepala daerah dan wakil kepala daerah Kabupaten Lombok Tengah Tahun 2010 Atas Nama H.Moh Suhaili FT.SH dan Drs.HL. Normal Suzana melanggar AsasAsas Umum Pemerintahan yang baik yaitu asas kepastian hukum, asas kecermatan asas persamaan dan asas larangan bertindak sewenang-wenang. d. Menyatakan batai Keputusan Tata Usaha Negara berupa Keputusan. e. Komisi Pemiihan Umum Daerah Lombok Tengah No.27 Tahun 2010 Tentang Penetapan Pasangan Calon Kepala Daerah Dan Wakil Kepala Daerah menjadi peserta pemilihan umum kepala daerah dan wakil kepala daerah Kabupaten Lombok Tengah Tahun 2010 Atas Nama H.Moh Suhaili FT.SH Dan Drs.HL. Normal Suzana. f. Mewajibkan tergugat untuk mencabut Keputusan tata Usaha Negara berupa Keputusan Komisi Pemilihan Umum Daerah Kabupaten Lombok Tengah No.27 Tahun 2010 Tentang Penetapan Pasangan Calon Kepala Daerah Dan Wakil Kepala Daerah menjadi peserta pemilihan umum kepala daerah dan wakil kepala daerah Kabupaten Lombok Tengah Tahun 2010 Atas Nama H.Moh Suhaili FT.SH Dan Drs.HL. Normal Suzana. g. Menolak gugatan pengugat selain dan selebihnya. h. Menghukum Tergugat membayar biaya perkara sebesar Rp.370.000 (tiga Ratus tujuh puluh ribu rupiah). ${ }^{17}$

Maka sifat dari Putusan Pengadilan Tata Usaha Negara tersebut adalah constitultief dan Condemnatoir, hai ini dikarenakan bahwa salah amar putusan tersebut Menyatakan batal Keputusan Tata Usaha Negara Keputusan Komisi Pemilihan Umum Kabupaten Lombok Tengah No. 27 Tahun 2010 Tentang Penetapan Pasangan Caion Kepala Daerah Dan Wakil kepala Daerah menjadi peserta pemilihan umum kepala daerah dan wakil kepala daerah Kabupaten Lombok Tengah Tahun 2010 Atas Nama H.Moh Suhaill FT.SH Dan

17

https://putusan3.mahkamahagung.go.id/direktori/putusan/zaebc8c90a40d7fe890830393 1383535.html/ https://ptun-mataram.go.id/layanan-publik/transparansi/laporan-tahunan 
Drs.HL. Normal Suzana. Ini artinya Putusan Pengadian Tata Usaha Negara Mataram yang meniadakan Keadaan hukum, dengan dibatalkannya Keputusan Komisi Pemilihan Umum Daerah Lombok Tengah No.27 Tahun 2010 tersebut putusan Komisi Pemiihan Umum Daerah Kalombok Tengah No.27 Tahun 2010 tidak mempunyai kekuatan hukum sehingga sifatnya constitutief. ${ }^{18}$

Selain itu amar putusan tersebut menyatakan Mewajibkan tergugat untuk mencabut Keputusan tata Usaha Negara berupa Keputusan Komisi Pemiihan Umum Daerah Kabupaten Lombok Tengah No.27 Tahun 2010 Tentang Penetapan Pasangan Calon Kepala Daerah Dan Wakil Kepala Daerah menjadi peserta pemilihan umum kepala daerah dan wakil kepala daerah Kabupaten Lombok Tengah Tahun 2010 Atas Nama H.Moh Suhaili FT.SH Dan Drs.HL. Normal Suzana, ini artinya, dimana amar tersebut berisi penghukuman yaitu Mewajibkan tergugat untuk mencabut Keputusan tata Usaha Negara berupa Keputusan Komisi Pemilihan Umum Kabupaten Lombok Tengah No. 27 Tahun 2010, sehingga sifatnya Condemnatoir. Akibat dari suatu putusan Condemnatoir adalah diberikannya hak kepada penggugat untuk meminta tindakan eksekutorial terhadap tergugat. ${ }^{19}$

\section{B. Pengertian dan Tata Cara Pelaksanaan Eksekusi}

Eksekusi adalah hal menjalankan putusan Pengadilan yang sudah berkekuatan hukum tetap. Selain itu menurut supomo eksekusi diartikan sebagai aturan tentang cara dan syarat-syarat yang dipakai oleh alat-alat negara, guna membantu pihak yang berkepentingan untuk menjalankan putusan hakim apabila pihak yang kalah tidak bersedia mematuhi substansi putusan dalam waktu yang ditentukan. Pendapat Supomo di atas menunjukkan adanya fungsi pembantuan dari aparat negara, untuk

${ }^{18}$ https://ptun-mataram.go.id/layanan-publik/transparansi/laporan-tahunan

${ }^{19}$ https://ptun-mataram.go.id/layanan-publik/transparansi/laporan-tahunan 
melaksanakan isi putusan tersebut manakala terjadinya pembangkangan pihak terhukum atas isi putusan. ${ }^{20}$

Salah satu yang menjadi kekuatan hukum dari Putusan Pengadilan adalah kekuatan eksekutorial, yang dimaksud dengan kekuatan hukum eksekutoriai dari putusan hakim adalah kekuatan hukum yang diberikan kepada suatu putusan hakim bahwa putusan hakim dapat dilaksanakan.

Sebagai syarat bahwa suatu putusan hakim memperoleh kekuatan eksekutorial adaiah dicantumkannya irah-irah "DEMI KEADILAN BERDASARKAN KETUHANAN YANG MAHA ESA" Selain itu hanya putusan yang bersifat condemnatoir yang mempunyai kekuatan eksekutorial sedangkan putusan Pengadilan yang bersifat deklaratoir dan constitutif tidak mempunyai kekuatan eksekusi.

Pada hakikatnya eksekusi tidak lain ialah realisasi daripada kewajiban pihak yang kaiah untuk memenuhi prestasi yang tercantum dalam putusan Pengadilan tersebut. Pihak yang menang dapat memohon eksekusi pada Pengadilan yang memutus perkara tersebut untuk melaksanakan putusan tersebut secara paksa (execution force).

Dalam pelaksanaan eksekusi dikenal beberapa asas yang harus dipegangi oleh pihak Pengadilan, yakni sebagai berikut:

a. Putusan Pengadilan harus sudah berkekuatan hukum tetap.

b. Putusan tidak dijalankan secara sukarela.

c. Putusan mengandung amar Condemnatoir.

d. Eksekusi di bawah pimpinan Ketua Pengadilan.

Tata cara eksekusi dalam hukum acara peradilan tata usaha negara diatur dalam Pasal 115 sampai dengan Pasal 119 Undang-Undang No.5 Tahun 1986 Tentang Pengadilan Tata Usaha Negara Jo. Undang-Undang 9 Tahun 2004 Jo.Undang-Undang No.51 Tahun 2009 Tentang Perubahan

20 115-116 UU Nomor 5 Tahun 1986 jo UU No. 9 Tahun 2004 jo UU No. 51 Tahun 2009. 
kedua atas Undang-Undang No.5 Tahun 1986 Tentang Pengadilan Tata usaha negara.

Pasal 115 menyebutkan hanya putusan pengadilan yang telah memperoleh kekuatan hukum tetap yang dapat dilaksanakan Sebelum putusan itu dilaksanakan terlebih dahulu pengadilan yang telah memperoleh kekuatan hukum tetap, dikirimkan kepada para pihak dengan surat tercatat oleh panitera pengadilan setempat atas perintah ketua pengadilan yang mengadilinya dalam tingkat pertama selambat lambatnya dalam waktu 14 (empat belas) hari kerja sebagaimana yang disebutkan dalam Pasal 116 ayat(1).

Apabila setelah 60 (enam puluh) hari kerja putusan pengadilan yang telah memperoleh kekuatan hukum tetap diterima, tergugat tidak melaksanakan kewajibannya untuk mencabut Keputusan Tata Usaha Negara yang bersangkutan maka keputusan tata usaha negara yang disengketakan itu tidak mempunyai kekuatan hukum lagi sebagaimana yang disebutkan dalam Pasal 116 ayat(2). ${ }^{21}$

Dalam hal tergugat ditetapkan harus melaksanakan kewajiban Untuk mencabut Keputusan Tata Usaha Negara yang bersangkutan dan menerbitkan Keputusan Tata Usaha Negara yang baru atau penerbitan Keputusan Tata usaha Negara daiam hal gugatan didasarkan pada Pasai 3, kemudian setelah 90 (sembilan puluh) hari kerja ternyata kewajiban tersebut tidak dilaksanakan, maka penggugat mengajukan permohonan kepada ketua pengadilan agar pengadilan memerintahkan tergugat melaksanakan putusan pengadilan tersebut. sebagaimana yang disebutkan dalam Pasal 116 ayat(3) 22

Dalam hal tergugat tidak bersedia melaksanakan putusan pengadilan yang telah memperoleh kekuatan hukum tetap, terhadap pejabat yang bersangkutan dikenakan upaya paksa berupa pembayaran sejumlah uang paksa dan/atau sanksi administratif. sebagaimana yang disebutkan dalam

21 115-116 UU Nomor 5 Tahun 1986 jo UU No. 9 Tahun 2004 jo UU No. 51 Tahun 2009.

22 115-116 UU Nomor 5 Tahun 1986 jo UU No. 9 Tahun 2004 jo UU No. 51 Tahun 2009. 
Pasal 116 ayat (4) Pejabat yang tidak melaksanakan putusan pengadilan diumumkan pada media massa cetak setempat oleh panitera sejak tidak terpenuhinya

Untuk mencabut Keputusan Tata Usaha Negara yang bersangkutan dan menerbitkan Keputusan Tata Usaha Negara yang baru atau penerbitan Keputusan Tata Usaha Negara dalam hal gugatan didasarkan pada Pasal 3 sebagaimana yang disebutkan dalam Pasal 116 ayat (5) ${ }^{23}$

Di samping diumumkan pada media massa cetak setempat, ketua pengadilan harus mengajukan hal ini kepada Presiden sebagai pemegang kekuasaan pemerintah tertinggi untuk memerintahkan pejabat tersebut melaksanakan putusan pengadilan, dan kepada lembaga perwakilan rakyat untuk menjalankan fungsi pengawasan. sebagaimana yang disebutkan dalam Pasal 116 ayat(6) 24

Ketentuan mengenai besaran uang paksa, jenis sanksi administratif, dan tata cara pelaksanaan pembayaran uang paksa dan/atau sanksi administratif diatur dengan peraturan perundang-undangan. Sebagaimana yang disebutkan dalam Pasal 116 ayat(7) berdasarkan ketentuan Pasai 116 tersebut diatas, sesungguhnya ada dua jenis eksekusi yang kita kenal di peradilan tata usaha Negara. ${ }^{25}$

1. Eksekusi terhadap putusan pengadilan yang berisi kewajiban sebagaimana dimaksud dalam Pasal 97 ayat (9) huruf a, yaitu kewajiban berupa pencabutan KTUN yang bersangkutan.

2. Eksekusi terhadap putusan pengadilan yang berisi kewajiban sebagaimana dimaksud dalam Pasal 97 (9) huruf b dan huruf c, yaitu : Huruf $\mathrm{b}$ : pencabutan kTUN yang bersangkutan dan menerbitkan

${ }^{23}$ 115-116 UU Nomor 5 Tahun 1986 jo UU No. 9 Tahun 2004 jo UU No. 51 Tahun 2009.

24 115-116 UU Nomor 5 Tahun 1986 jo UU No. 9 Tahun 2004 jo UU No. 51 Tahun 2009.

25 115-116 UU Nomor 5 Tahun 1986 jo UU No. 9 Tahun 2004 jo UU No. 51 Tahun 2009. 
KTUN yang baru; atau Huruf c : penerbitan KTUN dalam hal gugatan didasarkan pada Pasal 3.

Apabila terdapat adanya eksekusi jenis pertama, tergugat tidak melaksanakan kewajibannya dalam waktu 60 (enam puluh) hari, maka keputusan Tata Usaha Negara yang disengketakan itu tidak mempunyai kekuatan hukum lagi. Dengan demikian tidak perlu lagi ada tindakan-tindakan ataupun upaya-upaya lain dari pengadilan, misalnya surat peringatan dan sebagainya. Sebab Keputusan Tata Usaha Negara itu dengan sendirinya akan hilang kekuatan hukumnya. Cara eksekusi seperti ini disebut dengan eksekusi otomatis.

Sebaliknya apabila terdapat adanya eksekusi jenis kedua, dan tidak ditaati dalam waktu 90 (sembilan puluh), terhadap pejabat yang bersangkutan dikenakan upaya paksa berupa pembayaran sejumlah uang paksa dan/atau sanksi administratif dan diumumkan pada media massa cetak setempat oleh panitera.

Agar Putusan Pengadilan dapat dieksekusi dengan uang paksa, maka diperlukan beberapa syarat sebagai berikut: ${ }^{26}$

1. Pembebanan uang paksa harus dicantumkan dalam amar putusan pengadilan yang mengabulkan gugatan

2. Uang paksa ditetapkan oleh hakim karena jabatannya

3. Uang paksa dapat dilaksanakan pembebanannya kepada tergugat yang tidak bersedia melaksanakan putusan pengadilan yang berupa kewjiban sebagaimana yang dimaksud dalam Pasal 97 ayat (9) huruf b dan c, jika putusan pengadilan tersebut telah mempunyai kekuatan hukum tetap.

Penerapan Uang paksa (dwangsom) tidak dapat dapat diterapkan pada semua putusan Pengadilan Tata Usaha Negara. Penerapan dwangsom hanya dapat dibebankan pada putusan Pengadilan Tata Usaha

${ }^{26}$ 115-116 UU Nomor 5 Tahun 1986 jo UU No. 9 Tahun 2004 jo UU No. 51 Tahun 2009. 
Negara yang bersifat penghukuman (putusan condemnatoir). Pejabat Tata Usaha Negara yang sedang menjalankan tugasnya dalam kedinasan dan kemudian menimbulkan suatu kerugian bagi masyarakat, namun tugas tersebut dilaksanakan sesuai dengan hukum maka kerugian yang dialami masyarakat haruslah dibebankan kepada negara. Karena merupakan kesalahan teknis dalam menjalankan dinas.

Lain halnya jika pada saat pejabat Tata Usaha Negara tidak patuh untuk melaksanakan putusan PTUN maka pada saat tersebut pejabat TUN tidak sedang melaksanakan peran negara. Apabila terjadi hal demikian maka pertanggung jawabannya dibebankan secara pribadi kepada pejabat Tata Usaha Negara yang bersangkutan. Hal ini sesuai dengan teori kesalahan yang dikembangkan dari Yurisprudensi Counsil d'Etat yang membedakan kesalahan dinas (Faute de serve) dan kesalahan pribadi (Faute de personelle). ${ }^{27}$

Dalam hal pelaksanaan kewajiban Tergugat, untuk membayar ganti rugi sebagaimana yang disebutkan dalam Pasal 97 ayat( 10) UndangUndang No.5 Tahun 1986 Tentang Pengadilan Tata Usaha Negara, hal tersebut diatur dalam Peraturan pemerintah No 43 tahun 1991 tentang Ganti rugi dan Tata Cara Pelaksanaannya pada Pengadilan Tata Usaha Negara.

Proses ganti rugi sebagai pelaksanaan putusan Pengadilan Tata Usaha Negara, dimulai dengan dikirim kannya salinan putusan oleh Pengadilan Tata Usaha Negara yang menetapkan putusan tersebut, paling lama 3 (tiga) hari setelah putusan tersebut ditetapkan. Apabila putusan ganti rugi tersebut ditetapkan oleh Pengadilan Tinggi Tata Usaha Negara atau Mahkamah Agung, maka putusan tersebut harus dikirimkan pula kepada Pengadilan Tata Usaha Negara di tingkat pertama. Tergugat atau termohon atau badan tata usaha negara, yang dihukum membayar ganti rugi, setelah menerima permohonan atau pengajuan ganti rugi dari

27 Jimly Asshieddiqie, Pengantar limu Hukum Tata Negara, Sekretariat Jendral dan Kepanitraan Mahkamah Konstitusi RI Jakarta, 2006, 38. 
pencari keadilan/ penggugat tersebut, selanjutnya memberi tahukan kepada pencari keadilan bahwa permohonannya telah diterima. ${ }^{28}$

Pemberitahuan dari badan tata usaha negara atau termohon eksekusi atau tergugat tersebut, harus sudah di lakukan dengan surat tercatat paling lambat 30 (tiga puluh) hari sejak tanggal penerimaan surat permohonan dari pencari keadilan.

Adapun tata cara pembayaran ganti rugi yang menjadi beban APBN, berdasarkan Keputusan Menteri Keuangan RI No 1129/KM.01/1991 tentang Tata Cara Pembayaran Ganti Rugi Pelaksanaan Putusan Pengadilan Tata Usaha Negara, prosedurnya dimuiai dengan pengajuan permohonan Ketua PTUN atas permohonan Penggugat kepada Menteri cq. Sekretaris Jenderal atau Ketua Lembaga yang bersangkutan yang dikenakan ganti rugi, dilampiri putusan Pengadilan. Atas permohonan Ketua Pengadilan Tata Usaha Negara tersebut, maka Menteri atau Sekretaris Jenderal atau Ketua Lembaga yang dikenai ganti rugi, mengajukan permohonan Surat Kuasa Otorisasi (SKO) kepada Menteri Keuangan cq Direktur Jenderal Anggaran. Menteri Keuangan cq Direktur Jenderal Anggaran memeriksa permohonan berkas permohonan SKO tersebut. Apabila tidak ada keberatan atau kekurangan berkas, Menteri keuangan Ri cq Direktur Jenderal Anggaran menerbitkan SKO atas beban Bagian Pembiayaan dan Perhitungan Anggaran Belanja Negara Rutin. SKO Asli disampaikan kepada yang berhak. ${ }^{29}$

Berdasarkan SKO maka Penggugat mengajukan permohonan ganti rugi ke Kantor Perbendaharaan dan Kas Negara (KPKN) melalui badan tata usaha negara setempat (perwakilan BTUN yang dikenai ganti rugi) dengan melampir kan : a. Surat Keputusan Otorisasi

b. Asli dan salinan petikan Putusan Pengadilan yang sudah berkekuatan hukum tetap.

28 Jimly Asshieddiqie, Perkembangan dan Konsolidasi Negara Pasca Reformasi, Sekretariat Jendral dan Kepanitraan Mahkamah Konstitusi RI Jakarta, 2006, 38.

29 Jimly Asshieddiqie, Perkembangan dan Konsolidasi Negara Pasca Reformasi, Sekretariat Jendral dan Kepanitraan Mahkamah Konstitusi RI Jakarta, 2006, 39. 
Badan Tata Usaha Negara setempat mengajukan Surat Perintah Pembayaran Langsung (SPLS) kepada KPKN pembayar. KPKN kemudian menerbitkan Surat Perintah Membayar Langsung (SPMLS) kepada yang berhak, serta melakukan pembayaran. Terhadap putusan yang telah dibayarkan gantirugi, maka diberikan cap (stempel) bahwa telah dilakukan pembayaran ganti rugi .

Dalam hal termohon atau badan tata usaha negara/tergugat, belum dapat melakukan kewajiban pembayaran ganti rugi pada tahun anggaran yang sedang ber jalan, maka pembayaran ganti rugi ini harus dibayarkan atau dilaksanakan pada tahun anggaran berikutnya. Sebagaimana diatur dalam Pasal 8 PP No 43 tahun 1991 sebagai berikut:

Apabila pembayaran gantirugi tidak dapat dilaksanakan oleh Badan tata usaha negara dalam tahun anggaran yang sedang berjalan,maka pembayaran gantirugi dimasukkan dan dilaksanakan dalam tahun anggaran berikutnya berdasarkan ketentuan Pasal 8 PP No 43 tahun 1991 berarti jika pada tahun berikutnya pembayaran gantirugi belum bisa dilakukan, maka dapat dilakukan pada tahun berikutnya lagi, dan begitu seterusnya tanpa ada batasan waktu yang jelas. Dari ketentuan tersebut, tergambar bagaimana pola yang ditawarkan oleh Pengadilan Tata Usaha Negara untuk melaksanakan putusannya. Pada tahap awal, dilakukan dengan mendasarkan kepada kesadaran tergugat melaksanakannya ,dan kemudian menggunakan upaya paksa yang besifat administratif.

Kemudian dalam hal Sanksi Administrasi maka ketua pengadilan harus mengajukan hal ini kepada Presiden sebagai pemegang kekuasaan pemerintah tertinggi untuk memerintahkan pejabat tersebut melaksanakan putusan pengadilan, dan kepada lembaga perwakilan rakyat untuk menjalankan fungsi pengawasan. Apabila melihat hal tersebut, Presiden diposisikan sebagai pemegang pemerintahan tertinggi namun kewenangan Presiden dalam pasal 116 ayat (6) tersebut hanya menyangkut pada hal (peristiwa) Pejabat Tata Usaha Negara yang tidak melaksanakan putusan Pengadilan Tata Usaha Negara yang berkekuatan hukum tetap hanya 
disebutkan dengan menggunakan kata "memerintahkan", yang sama sekali tidak memiliki unsur sanksi. ${ }^{30}$

Penegasan kewenangan Presiden secara Implisit dalam pasal 116 ayat (6) demi memberi perlindungan hukum Penggugat, maka terlihat penegakan hukum lebih dikembalikan kepada pemerintah sendiri dalam hal ini pejabat atasannya. Cara eksekusi seperti ini disebut dengan eksekusi hierarkis.

\section{Kekuatan Eksekutorial Putusan PTUN}

Keberadaan Peradilan Tata Usaha Negara diadakan dalam rangka memberikan perlindungan kepada rakyat pencari keadilan, yang merasakan dirinya dirugikan akibat suatu Keputusan Tata Usaha Negara. Pada dasarnya setiap putusan Pengadilan Tata Usaha Negara yang amarnya bersifat condemnatoir mempunyai kekuatan eksekutorial setelah putusan tersebut memiliki kekuatan hukum tetap, hal ini dikarenakan putusan tersebut berisi penghukuman bagi para tergugat, sehingga diperlukan adanya kekuatan memaksa bagi para tergugat yang tidak melaksanakan putusan Pengadilan Tata Usaha Negara. ${ }^{31}$ Pada awalnya mekanisme eksekusi Peradilan Tata Usaha Negara, yang lebih mengandalkan adanya keterjalinan hubungan hierarkhi struktural administrasi "atas bawah" seperti yang ada pada desain sistem berdasar Pasal 115 dan 116 UU 5 tahun 1986, jelas didasarkan kepada kondisi yang ada pada saat undang undang tersebut dibuat. Di mana praktek kenegaraan saat itu (era Presiden Suharto), sangat bertumpu pada ujung kekuasaan yang sangat kuat, sehingga diharapkan pada ujung kekuasaan yang akan menimbulkan rasa "patuh atau takut" bagi bawahan yang tidak mau melaksanakan.

Sementara kondisi saat ini, dimana hubungan pemerintah pusat daerah diatur menurut UU No 32 Tahun 2004 tentang Pemerintah Daerah, lebih menekankan kepada demokratisasi dan otonomisasi

30 Atmosudirdjo Prajudi, Masalah Organisasi Peradilan Administrasi Negara, Simposium PTUN, BPHN-Binacipta, Bandung. 1977.

31 Jimly Asshieddiqie, Perkembangan dan Konsolidasi Negara Pasca Reformasi, Sekretariat Jendral dan Kepanitraan Mahkamah Konstitusi RI Jakarta, 2006, 40. 
kekuasaan, tentu merupakan prakondisi yang sudah tidak sesuai lagi dengan sistem yang ada.

Adanya perubahan Pasal 116 Undang-undang no 5 tahun 1986 menjadi Undang-Undang No 9 tahun 2004, merubah sistem pelaksanaan putusan. dari menyandarkan diri kepada struktural birokrasi atas bawah, menjadi sistem yang menyandarkan kepada pola upaya paksa, melalui massa media dan uang paksa serta sanksi administrasi." Dari ketentuan Pasal 116 Undang-Undang No.51 Tahun 2009 tentang perubahan kedua atas Undang-Undang No.5 Tahun Tentang Pengadilan Tata Usaha Negara mengatur mengenai unsur paksaan administratif seperti: ${ }^{32}$

1. Uang Paksa

2. Sanksi administrative

3. Diumumkan di media massa.

Walaupun ketentuan dalam Undang-Undang Pengadilan Tata Usaha Negara telah memuat ketentuan mengenai unsur paksaan akan tetapi dalam pelaksanaannya terkadang putusan Pengadilan Tata Usaha Negara tidak mempunyai kekuatan eksekusi, sehingga tidak dapat memberikan perlindungan perlindungan kepada rakyat pencari keadilan, yang merasa dirinya dirugikan akibat suatu Keputusan Tata Usaha Negara, hal ini dkarenakan tidak ada aparat atau badan yang bersifat memaksa untuk melakukan eksekusi agar tergugat melaksanakan putusan Pengadilan Tata Negara seperti halnya putusan yang bersifat condemnatoir dalam peradilan perdata maupun pidana. ${ }^{33}$

Kondisi demikian menunjukkan bahwa keberhasilan dari laksanaan putusan, harus mendapatkan dukungan dari aparat determinant factor sehinggapenekanannya lebih ke pertanggung jawaban hukum Hal ini mengandung arti ,hukum dengan segenap instrumen pemaksanya,yang akan memaksa seseeorang untuk melakukan isi putusan tersebut .

32 115-116 UU Nomor 5 Tahun 1986 jo UU No. 9 Tahun 2004 jo UU No. 51 Tahun 2009.

33 Amirudin Ibramsyan, Kedudukan KPU Daiam Struktur Ketatanegaraan Republik Indonesia Pasca Amandemen UUD 1945, Jakarta: Laksbang Mediatama, 2008, 76. 
penegakan putusan pengadilan Tata Usaha Negara diletakan kepada kesadaran hukum dari penjabat Tata Usaha Negara tidak ada instrumen yang dapat memaksa tergugat untuk mematuhi dan melaksanakan keputusan . pelaksanaan putusan PTUN ,sangat begantung kepada kesadaran hukum dari tergugat. Meskipun dimungkinkan adanya upaya paksa, tetapi upaya paksa yang ditawarkanpun juga tetap tidak mampu menjawab permasalahan. Permasalahan tersebut semakin bertambah , dengan kenyataan, tanggungjawab terhadap perkara tata uasaha negara bukanlah tanggungjawab yang bersifat personal atau pribadi. Didalam perkara tata usaha negara, kedudukan tanggung jawab hanya kepada jabatan saja, sehingga beban moral yang dipikul tergugat tidak terlalu besar $^{34}$.

Sementara di sisi yang sama, tidak dimungkinkan dilakukannya penjaminan, seperti paya sita terhadap harta benda milik tergugat yang berguna untuk terjaminnya pelaksanaan PTUN ( hal ini karena berdasar ketentuan hukum keuangan negara maupun perbendaharaan negara tidak dimungkinkan dilakukan sita conservatoir ataupun eksekutorial atas inventaris atas investaris milik negara. Selain itu adanya asas hukum administrasi yang diraksakan menghambat pelaksanaan eksekusi putusan pengadilan tata Usaha Negara.

\section{E. Kesimpulan}

Berdasarkan uraian pembahasan di atas dapat diperoleh kesimpulan sebagai berikut : pertama; Mekanisme eksekusi terhadap putusan Pengadilan Tata Usaha Negara yang berlaku sekarang berdasarkan ketentuan Undang-Undang No. 51 Tahun 2009 Tentang Peradilan Tata Usaha Negara yaitu : Putusan Pengadilan yang telah inkracht, dikirimkan kepada para pihak dengan surat oleh panitera pengadilan setempat atas perintah Ketua Pengadilan yang mengadi linya dalam tingkat pertama selambat-lambatnya dalam waktu 14 hari kerja, Apabila setelah 60 hari kerja putusan yang telah memperoleh kekuatan hukum tetap yang diterima tergugat tidak me laksanakan kewajibannya

34 Amirudin Ibramsyan, Kedudukan KPU Daiam Struktur Ketatanegaraan Republik Indonesia Pasca Amandemen UUD 1945, Jakarta: Laksbang Mediatama, 2008, 76. 
maka keputusan tata usaha Negara yang disengketakan itu tidak mempunyai kekuatan hukum lagi, Tergugat ditetapkan harus melaksanakan kewajiban setelah 90 (sembilan puluh) hari kerja ternyata kewajiban tersebut tidak dilaksana kan, maka penggugat mengajukan per mohonan kepada Ketua Pengadilan agar Pengadilan me merintahkan tergugat melak sana kan putusan peng adilan tersebut, Tergugat tidak bersedia melaksanakan putusan Pengadilan yang telah memperoleh ke kuatan hukum tetap, terhadap pejabat bersangkutan dikenakan upaya paksa berupa pembayaran sejumlah uang paksa dan atau sanksi adminsitratif, Pejabat TUN yang tidak melaksanakan putusan pengadilan maka diumumkan pada media massa cetak setempat oleh panitera sejak tidak terpenuhinya.

Secara keseluruhan peraturan mengenai sanksi disiplin terhadap para pejabat yang tidak melaksanakan putusan TUN telah diatur dengan jelas dalam Undang undang Nomor 30 Tahun 2014 tentang Administrasi Pemerintahan dan Peraturan Peemrintah Nomor 48 Tahun 2016 tentang Tata Cara Pengenaan Sanksi Administratif Kepada Pejabat Pemerintahan, akan tetapi dalam pelaksanaannya masih banyak yang tidak melaksanakan aturan tersebut, oleh karena itu, ini merupakan tugas pejabat pembinan kepegawaian selaku atasan untuk lebih responsive terhadap permasalahan tersebut, karena apabila tidak dilakukan maka tentunya yang akan dirugikan adalah masyarakat.

DAFTAR PUSTAKA

Atmosudirdjo Prajudi, Masalah Organisasi Peradilan Administrasi Negara, Simposium PTUN, BPHN-Binacipta, Bandung. 1977. 
Amirudin Ibramsyan, Kedudukan KPU Daiam Struktur Ketatanegaraan Republik Indonesia Pasca Amandemen UUD 1945, Jakarta: Laksbang Mediatama, 2008.

Arifin Marpaung, "Pelaksanaan Putusan Pengadilan Tata Usaha Negara Melalui Upaya Paksa”, Disertasi Program Pascasarjana Universitas Airlangga Surabaya, 2010.

Adrian Bedner, Administrative Courts in Indonesia : A Socio-Legal Study (Terjemahan), London, The Hague: Kluwer International, 2003.

Assiddiqie, Jimly. Sengketa Kewenangan Antar Lembaga Negara, Konstitusi Press, Jakarta, 2006.

Assiddiqie, Jimly. Negara Hukum Indonesia, Ceramah Umum dalam rangka Pelantikan Dewan Pimpinan Pusat Ikatan Alumni Universitas Jayabaya, di Jakarta, Sabtu, 23 Januari 2010.

Assiddiqie, Jimly. Perkembangan dan Konsolidasi Negara Pasca Reformasi, Sekretariat Jendral dan Kepanitraan Mahkamah Konstitusi RI Jakarta, 2006.

Assiddiqie, Jimly. Konstitusi dan Kostitusionalisme Indonesia, Sinar Grafika, Jakarata, 2010, 76.

Assiddiqie, Jimly. Sengketa Kewenangan Antar Lembaga Negara, Konstitusi Press. Jakarta, 2006.

Assiddiqie, Jimly. Pengantar limu Hukum Tata Negara, Sekretariat Jendral dan Kepanitraan Mahkamah Konstitusi RI Jakarta, 2006.

Assiddiqie, Jimly. Perkembangan dan Konsolidasi Negara Pasca Reformasi, Sekretariat Jendral dan Kepanitraan Mahkamah Konstitusi RI Jakarta, 2006.

Assiddiqie, Jimly. Perkembangan dan Konsolidasi Negara Pasca Reformasi, Sekretariat Jendral dan Kepanitraan Mahkamah Konstitusi RI Jakarta, 2006.

Ibrahim, Johny. Teori Metodologi Penelitian Hukum Normatif. Malang: Banyu Media, 2008.

Simon Butt, The Eksekusi of the Negara Hukum : Implementing Judicial Decision in Indonesia, dalam Timothy Lindsey (Editor), Indoneisa : Law and Society, The Federation Press, Melbourne, 1999.

Supandi, "Kepatuhan Pejabat Dalam Menaati Putusan Pengadilan Tata Usaha Negara", (Disertasi Program Pascasarjana Universitas Sumatera Utara; Medan), 2005. 
Mahmud Marzuki, Peter. Penelitian Hukum. Jakarta: Kencana Prenada Media Group, 2010

https://putusan3.mahkamahagung.go.id/direktori/putusan/zaebc8c90a40d 7fe8908303931383535.html/ https://ptun-mataram.go.id/layananpublik/transparansi/laporan-tahunan

https://ptun-mataram.go.id/layanan-publik/transparansi/laporan-tahunan.

115-1 16 UU Nomor 5 Tahun 1986 jo UU No. 9 Tahun 2004 jo UU No. 51 Tahun 2009. 